\title{
Fine root production and distribution in the tropical rainforests of south-western Cameroon: effects of soil type and selective logging
}

\begin{abstract}
Ibrahima A ${ }^{(1)}$, Mvondo ZE A ${ }^{(2)}$, Ntonga JC ${ }^{(3)}$
Little information on fine roots that play an important role in nutrient cycling was available in tropical rainforests. Distribution of fine root production and effects of selective logging on root biomass and nutrient content change were studied in the tropical rainforests of south-western Cameroon. Twenty five root samples were excavated in each of two soil depths $(0-10$ and $10-25 \mathrm{~cm})$ and in each of three undisturbed forests (Ebom, Ebimimbang and Nyangong) and one disturbed forest by logging, using a square metallic frame of $25 \times 25$ $\mathrm{cm}$ and $30 \mathrm{~cm}$ high. Root samples were categorized in three diameter classes: fine $(<2 \mathrm{~mm})$, small $(2-5 \mathrm{~mm})$ and medium roots $(5-20 \mathrm{~mm})$. Root biomass of three diameter classes and nutrients $(\mathrm{N}, \mathrm{Ca}, \mathrm{Mg}, \mathrm{K}, \mathrm{Na}$ and $\mathrm{P})$ of the two first diameter classes were determined. Results have shown that total root biomass varied from 9.62 (Ebom) to $29.88 \mathrm{t} \mathrm{ha}^{-1}$ (Ebimimbang); those of fine roots decreased from Nyangong $\left(7.43 \mathrm{t} \mathrm{ha}^{-1}\right)$ to Ebom $\left(1.74 \mathrm{t} \mathrm{ha}^{-1}\right)$. In the top soil, the fine root biomass was 2 to 4 time lower in Ebom $\left(1.43 \mathrm{t} \mathrm{ha}^{-1}\right)$ than in other undisturbed forests $\left(3.28\right.$ and $\left.5.87 \mathrm{t} \mathrm{ha}^{-1}\right)$. From 70 to $80 \%$ of fine root biomass were produced in the first 10 centimeters of soil depth. Nutrient amount in fine root biomass were also lower in Ebom than in Ebimimbang and Nyangong, except the $\mathrm{P}$ amount $\left(\mathrm{kg} \mathrm{ha}^{-1}\right)$ which remained high in Ebom. On the contrary, no pattern of nutrient content $\left(\mathrm{g} \mathrm{kg}^{-1}\right)$ changes among forest were found, except $\mathrm{N}$ and $\mathrm{P}$ that decreased from Ebom to Nyangong. Six years after logging, its effects on root biomass and nutrient changes were not significant and during this period, root production of disturbed forest was high due to rapid regeneration of forest particularly heliophilous tree species.
\end{abstract}

Keywords: Fine roots, Root biomass, Nutrients, Logging, Tropical rainforest, Cameroon

\section{Introduction}

The tropical rainforests of southern Cameroon as African rainforests are subjected to deforestation due to shifting cultivation, commercial timber and forest exploita-

(1) Department of Biological Sciences, University of Ngaoundere, P. O. Box 454, Ngaoundéré (Cameroon); (2) Faculty of Agronomy and Agricultural Sciences, University of Dschang, P. O. Box 234, Dschangs (Cameroon); (3) Institute of Geological and Mining Research, P. O. Box 4110, Yaoundé (Cameroon)

(a) Adamou Ibrahima

(aibrahima@hotmail.com)

Received: Oct 21, 2009 - Accepted: Jun 05, 2010

Citation: Ibrahima A, Mvondo ZE A, Ntonga $J C, 2010$. Fine root production and distribution in the tropical rain forests of south-western Cameroon: effects of soil type and selective logging. iForest 3: 130-136 [online: 2010-09-27] URL: http://www.sisef. it/iforest/show.php?id=549 tion (Archard et al. 2002). This is stimulated by demographic and economic crisis forces. To counteract this process, the Cameroonian government has decided to develop, through the Tropenbos Cameroon Programme (TCP), methods and strategies for sustainable management of his rainforests (Foahom \& Jonkers 1992). Fine roots are one of the factors to take into consideration in sustainable forest management, because of their critical role in nutrient cycling and tree regeneration (Saterson \& Vitousek 1984). No information on roots is currently available for the tropical rainforests of southern Cameroon, especially on their changes among forest types and the rate of their recovery after selective logging.

Because of their high nutrient absorption capacity and quick turnover, fine roots $(0.5$ to $2 \mathrm{~mm}$ diameter) play a key role in nutrient cycles (Castellanos et al. 2001). These roots tend to concentrate in the upper layers of the soil containing most of the nutrients released from decomposing litter. It is therefore a nutrient conservation mechanism in forests
(Jordan 1991). Fine roots which are dynamic components of below-ground biomass represent about $30 \%$ of the above-ground biomass (Noordwijk et al. 1996) and between 40 and $85 \%$ of the net primary production according to the soil type (Hoffmann \& Usoltsev 2001). The mortality and decomposition of fine roots contribute substantially to the carbon and nutrients stock in the soil. This contribution is equivalent (or even higher) to that of litterfall that returns carbon and nutrients from canopy to the soil (Hendrick \& Pregitzer 1993).

Most of the research on fine roots has been carried out in the temperate region (Vogt et al. 1986). However, available information on tropical forests, even though insufficient, show that fine root biomass is higher in tropical forests $\left(4.5-92.5 \mathrm{t} \mathrm{ha}^{-1}\right)$ than in the temperate ones $\left(0.5-13.0 \mathrm{t} \mathrm{ha}^{-1}\right.$ - Noij et al. 1993). Root biomass assessments as well as the study of root distribution in forest were very studious processes (Hendricks et al. 2006) because of the difficulty involved in sampling and extraction (Noij et al. 1993, Hoffmann \& Usoltsev 2001). Moreover, contrary to the situation in temperate forests, where the period of dead vegetation material including roots and turnover are asynchronous, the production and mortality of fine root occur simultaneously, making it difficult to distinguish between living and dead roots.

The aim of the present work is to assess the change of fine root biomass and their nutrient content in three undisturbed forests, developed on different soil types according to soil Taxonomy-USDA and differed also by soil chemical characteristic as $\mathrm{K}, \mathrm{Mg}$ and $\mathrm{Ca}$ amount $\left(\mathrm{t} \mathrm{ha} \mathrm{h}^{-1}\right)$ and available $\mathrm{P}$ and water content (Van Gemerden \& Hazeu 1999). The rate of fine root and their nutrient recovery after selective logging are also examined.

\section{Material and methods}

\section{Study area}

Study sites are situated in the TCP (Tropenbos Cameroon Programme) research area, located in the western part of the Biafran Atlantic forest of south Cameroon (Letouzey 1985). This part of forests covers an area of about $2000 \mathrm{~km}^{2}$ and is bordered by the villages of Lolodorf, Akom II and Bipindi (Fig. 1). The bed rock is composed of Precambrian metamorphic as well as old volcanic rocks (Franqueville 1973). The soil characteristics vary with altitude. Between 50 and $350 \mathrm{~m}$ a.s.1, soil is a mixture of sand and clay and moderately acidic, whereas around $500 \mathrm{~m}$ a.s.l., it is highly clayey and strongly acidic (Van Germerden \& Hazeu 1999). The climate is the humid tropical type with four seasons; a long (from mid- novem- 


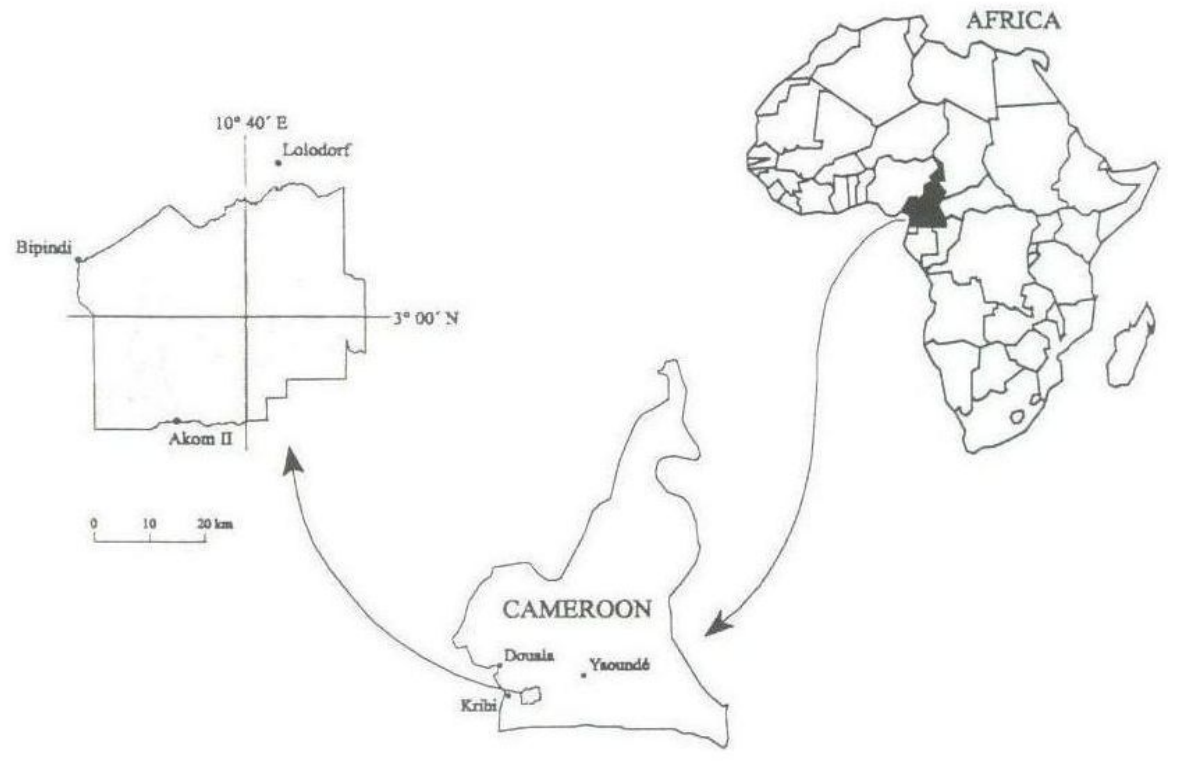

Fig. 1 - Location of TCP research area in southwest Cameroon.

ber to mid-march) and a short dry season (from mid-may to mid-august); a short (from mid-march to mid may) and a long rainy season (from mid-august to mid-november). Rainfall decreases progressively from the west to the east of the study area with an annual average of $2836 \mathrm{~mm}$ at Kribi, $2096 \mathrm{~mm}$ at Lolodorf and $1719 \mathrm{~mm}$ at Ebolowa, and annual average temperature ranges from $26.4^{\circ} \mathrm{C}$ at Kribi, 24.6 at Lolodorf and 24.0 ${ }^{\circ} \mathrm{C}$ at Ebolowa (Olivry 1986).

The vegetation of the TCP research area is part of this rainforest. The western and central portions of this area, with an altitude of slightly less than $700 \mathrm{~m}$ a.s.l., are covered by a evergreen forest characterised by tall trees that reach heights of about $60 \mathrm{~m}$ as well as by the presence of Calpocalyx dinklagei, Hymenostegia afzeillii and Saccoglottis gabonensis (Van Gemerden \& Hazeu 1999). The first two one are medium-sized tree (MT) with DBH (diameter of breast height) ranges from 20 to $60 \mathrm{~cm}$ and height from 15 to $40 \mathrm{~m}$. The last is large tree (LT) with DBH $>60 \mathrm{~cm}$ and total height $>40 \mathrm{~m}$. The Eastern part is mountainous and covered by a submontane forest, with a canopy that varies between 15 and $20 \mathrm{~m}$ high. Characteristic species are Anisophyllea polyneura (LT), Maranthes glabra (MT) and Scorodophloeus zenkeri (LT). The forest has been logged in recent years especially in the eastern part, with the exception of the mountainous parts, by national and international

Tab. 1 - Location and geomorphologic, pedologic and climate characteristics of study sites. (*): mean annual rainfall from 1996 to $2000 ;(* *)$ : soil depth: $0-10 \mathrm{~cm}$. Source: van Gemerden \& Hazeu (1999).

\begin{tabular}{lccc}
\hline \multicolumn{1}{c}{ Characteristics } & Ebimimbang (B) & Ebom (A1) & Nyangong (N) \\
\hline Location & $3^{\circ} 03^{\prime} \mathrm{N}, 10^{\circ} 28^{\prime} \mathrm{E}$ & $3^{\circ} 05^{\prime} \mathrm{N}, 10^{\circ} 41^{\prime} \mathrm{E}$ & $2^{\circ} 58^{\prime} \mathrm{N}, 10^{\circ} 45^{\prime} \mathrm{E}$ \\
Altitude (m a.s.1.) & 100 & 440 & $>600$ \\
Rainfall $(\mathrm{mm}) *$ & 1817 & 2115 & 1983 \\
Relief intensity $\left(\mathrm{m} \mathrm{km}^{-1}\right)$ & low $(<30)$ & moderate $(30-80)$ & high $(120-250)$ \\
River density & high & moderate & low \\
Vegetation & lowland forest & lowland forest & sub-montan forest \\
Land uses & high logging and & low logging and & logging absent and \\
& agriculture & agriculture & low agriculture \\
Soil types & ultisols & ultisols/oxisols & oxisols \\
Clay $(0-20 \mathrm{~cm}-\%)$ & $0-25$ & $20-50$ & $35-70$ \\
Clay $(20-60 \mathrm{~cm})$ & $20-45$ & $35-60$ & $50-80$ \\
Sandy $(\%)^{* *}$ & $60-90$ & $40-60$ & $10-40$ \\
pH $($ water) & 6.1 & 4.7 & 4.3 \\
Carbon $(\%)^{* *}$ & $2-3.5$ & $4-8$ & $4-9$ \\
Nitrogen $(\%)^{* *}$ & $0.15-0.35$ & $0.25-0.50$ & $0.25-0.40$ \\
\hline
\end{tabular}

companies, principally the Netherlands Company, WIJMA - Douala SARL (GWZ Van Gemerden \& Hazeu 1999). The logging rate was low; averaging $10 \mathrm{~m}^{3} \mathrm{ha}^{-1}$, say 0.7 tree $\mathrm{ha}^{-1}$ the last exploitation (Van Gemerden \& Hazeu 1999). Only trees with $\mathrm{DBH} \geq 80$ $\mathrm{cm}$ and straight boles of at least six meters were felled. Damages caused by this felling and extraction of the logs from the stand affected less than $8 \%$ of the forest area (Jonkers \& Van Leersum 2000, Fines et al. 2001). At some places in the forest Bantou people practice shifting agriculture with short fallows of Chromolaena odorata ( $A s$ teraceae - Nounamou \& Yemefack 2000), while Banyeli Pygmee live from gathering and hunting. Many non timber forest products are harvested (Van Dijk 1999).

\section{Site selection}

In the TCP research area, three experimental sites were chosen, at Ebimimbang, Ebom and Nyangong, corresponding respectively to low (100 m a.s.l.), median (about $440 \mathrm{~m}$ ) and high altitude $(>600 \mathrm{~m})$ forest zones. Moreover, these forests differ in soil types (Ultisols in Ebimimbang, Oxisols/Ultisols in Ebom and Oxisols in Nyangong) as well as in soil nutrient content like available P (Van Gemerden \& Hazeu 1999). Their geographical location and the climatic, geomorphological, and pedological characteristics are presented in Tab. 1. These three sites are also equally characterized by the absence of any recent natural or anthropogenic disturbance, excepted in the part of Ebom forest, and located near the hydrological experimental sites (Ntonga et al. 2002).

In each of the three sites, five plots of 100 $\mathrm{m}^{2}$ were chosen at random. To evaluate the impact of logging on the variation of fine root biomass, five other plots of $100 \mathrm{~m}^{2}$ were chosen in a part of the Ebom forest logged 6 years before. In each plot, five sub-plots of 1 $\mathrm{m}^{2}$ were selected, 1 at the 4 corners and other one in the middle of the plot (Kotto-same et al. 1997).

\section{Root Sampling}

Root sampling was carried out during the long dry season of 2001 (january - early march). All the sub-plots were carefully cleared manually of grass and litter, taking care not to damage the superficial roots. A root pre-sampling was carried out in another part of the forest and it showed that most of the fine roots are located in the upper $10 \mathrm{~cm}$ of the soil. In each of the 100 sub-plots of 1 $\mathrm{m}^{2}$, a block of soil was excavated in the middle at two different depths (0-10 and 10 $25 \mathrm{~cm}$ ) using a metal frame of a $25 \mathrm{~cm}$ side and $30 \mathrm{~cm}$ high, making a total of 200 samples. The soil blocks (cores) containing these roots were transported to the river and washed over a sieve with a $0.5 \mathrm{~mm}$ mesh. These roots samples were then collected by 
hand and stored in labelled paper bags and transported to the laboratory at Kribi, where they were dried in the oven at $60^{\circ} \mathrm{C}$ for $48 \mathrm{~h}$ They were then separated according to diameter classes in keeping with the model of Vogt \& Persson (1991): fine roots $(<2 \mathrm{~mm})$, small roots $(2-5 \mathrm{~mm})$ and medium roots $(5$ $20 \mathrm{~mm})$. The biomass of each root category, expressed in dry mass tonnes per hectare $\left(\mathrm{t} \mathrm{ha}^{-1}\right)$ was determined by weighing after drying in the oven at $60^{\circ} \mathrm{C}$ for $24 \mathrm{~h}$ to eliminate residual humidity.

\section{Chemical analysis}

The 25 samples of each of the first two diameter class (fine and small roots) by each depth of each forest type were lumped in three main replicates. This gave 12 samples ( 3 replicates $\times 2$ diameter classes $\times 2$ depths) to chemical analyse per forest type. The medium category ( 5 - $20 \mathrm{~mm}$ diameter) was not included in the chemical analysis because only very few roots were collected here Powder samples, obtained after grounding in a Micro Hammer Mill Culatti grounder equipped with a $1 \mathrm{~mm}$ link filter, were analysed. The samples were first mineralized by passing the plant powder through an oven at $550^{\circ} \mathrm{C}$ for 40 minutes. The ashes were diluted with a $\mathrm{HNO}_{3}$ solution for nutrient analysing: $\mathrm{K}$ and $\mathrm{Na}$ were analysed by flame spectrophotometer, $\mathrm{P}$ by vanado - molybdate colorimeter and $\mathrm{Ca}$ and $\mathrm{Mg}$ by atomic $\mathrm{ab}$ sorption spectrophotometer. $\mathrm{N}$ was assessed by the Kjeldhal method (titration by sulphuric acid at $0.01 \mathrm{~N}$ )

\section{Statistical analysis}

Before performing any statistical analysis, all variables were tested for normality and if necessary transformed. The comparison among undisturbed forests for the root biomass and the nutrient quantity was carried out by using ANOVA, followed by Scheffe's test at $5 \%$ if ANOVA is significant. A Student's test was used to compare soil depths, root diameter classes as well as the disturbed and undisturbed parts of the Ebom forest. These tests were conducted using SX statistical software (version 4.0, Analytical software 1992).

\section{Results}

Root biomass

\section{Variation among three undisturbed forests}

The root biomass did not differ significantly between diameter classes, except at Nyangong, at overall depth of $0-25 \mathrm{~cm}$, and at Ebimimbang, at depth of $0-10 \mathrm{~cm}$ and 0 $25 \mathrm{~cm}$ (Tab. 2). For these two depths, the means comparison through the Scheffer's test shows that the small and fine roots do not differ significantly in their biomass. This biomass tends to decrease with depth in these three forest types (for example, for fine roots from 1.4 to 0.3 at Ebom, from 3.3 to 1.4 at Ebimimbang and from 5.9 to $1.6 \mathrm{t} \mathrm{ha}^{-1}$ at Nyangong). Only at Ebom, small roots increase with depth (from 1.2 to $3.4 \mathrm{t} \mathrm{ha}^{-1}$ ).

Root biomass varies among forest types for each diameter classes and soil depth (Tab. 2). In general, root biomass difference is significant only for the fine and medium roots at depths of $0-10 \mathrm{~cm}$ and at the overall considered soil depth $(0-25 \mathrm{~cm})$. Fine root biomass decreases significantly from Nyangong (5.87 and $\left.7.43 \mathrm{t} \mathrm{ha}^{-1}\right)$ to Ebom (1.43 and $\left.1.74 \mathrm{ha}^{-1}\right)$; medium root biomass decreases from Ebimimbang (16.38 and 20.98 $\mathrm{ha}^{-1}$ ) to Ebom (1.95 and $\left.3.31 \mathrm{ha}^{-1}\right)$. On the other hand, there is no significant difference among forests for small root biomass, no matter the depth.

\section{Variation between undisturbed and dis- turbed forests at Ebom}

Due to the large variation per site (high S.E.), root biomass is not significant different between the disturbed and undisturbed forest, except the total amount of the fine root biomass, which is significantly higher in the disturbed than undisturbed forest (Tab. 2). In disturbed as well as undisturbed forests, small root biomass tends to increase with depth, while that of fine roots tends to decrease.

\section{Nutrients}

\section{Variation among three undisturbed forests}

Nutrient contents $\left(\mathrm{g} \mathrm{kg}^{-1}\right)$ of fine and small roots at two soil depths of three forests are given in Tab. 3. They vary according to the forest, depth, diameter class and nutrient considered. The variations of $\mathrm{N}$ and $\mathrm{P}$ contents among forests are similar. They tend to decrease from Ebom (N: 20.8; 17.2; 21.7 and P: $\left.1.4 ; 1.4 ; 1.8 \mathrm{~g} \mathrm{~kg}^{-1}\right)$ to Ebimimbang $(\mathrm{N}$ : $8.8 ; 7.4 ; 6.7$ and P: $\left.0.4 ; 0.4 ; 0.4 \mathrm{~g} \mathrm{~kg}^{-1}\right)$ respectively for the small roots at the two depth and for fine roots at a depth of 10-20 $\mathrm{cm}$ (Tab. 3). In topsoil, these two nutrients tend to decrease from Ebom (N: 18.7 and P: $2.0 \mathrm{~g} \mathrm{~kg}^{-1}$ ) to Nyangong (N: 11.6 and P: $0.5 \mathrm{~g}$ $\mathrm{kg}^{-1}$ ) for fine roots. $\mathrm{Mg}$ content decreases from Nyangong $\left(0.8 ; 0.5\right.$ and $\left.0.9 \mathrm{~g} \mathrm{~kg}^{-1}\right)$ to Ebimimbang $\left(0.5 ; 0.3\right.$ and $\left.0.3 \mathrm{~g} \mathrm{~kg}^{-1}\right)$ respectively for the two first diameter classes at a depth of $0-10 \mathrm{~cm}$ and small roots at a

Tab. 2 - Mean root biomass (standard errors in parenthesis) in $\mathrm{t} \mathrm{ha}^{-1}$ of dry mass in the three undisturbed forest types and a disturbed forest of southern Cameroon. Different letters indicate that the values are significantly different. $\mathrm{a}$ et $\mathrm{b}$ for comparison of diameter classes of the roots (vertical) and $\alpha$ and $\beta$ for comparison of three forest types: A1, B and N (horizontal). Student $\mathrm{t}_{\mathrm{A} 1 \mathrm{~A} 2}$ for comparison between undisturbed (A1) and disturbed (A2) forests. (ns): no significant; (*): $\mathrm{P}<0.05 ;(* *): \mathrm{P}<0.01 ;(* * *): \mathrm{P}<0.001$.

\begin{tabular}{|c|c|c|c|c|c|c|c|}
\hline \multirow{2}{*}{$\begin{array}{l}\text { Soil depths } \\
\quad \text { (cm) }\end{array}$} & \multirow{2}{*}{$\begin{array}{c}\text { Diameter } \\
\text { classes of roots } \\
(\mathbf{m m})\end{array}$} & \multicolumn{3}{|c|}{ Undisturbed forests } & \multicolumn{3}{|c|}{ Disturbed Forests } \\
\hline & & $\mathbf{F}_{\text {BNA1 }}$ & Ebimimbang (B) & Nyangong (N) & Ebom (A1) & Ebom (A2) & Student $\mathrm{t}_{\mathrm{A} 1 \mathrm{~A} 2}$ \\
\hline \multirow[t]{4}{*}{$0-10$} & $<2$ & $4.23^{*}$ & $3.28(1.62) \mathrm{b} \alpha \beta$ & $5.87(3.31) \beta$ & $1.43(1.22) \alpha$ & $2.78(0.69)$ & $1.93 \mathrm{~ns}$ \\
\hline & $2-5$ & $3.29 \mathrm{~ns}$ & $3.13(0.97) b$ & $3.47(2.04)$ & $1.15(0.83)$ & $1.51(0.49)$ & $0.75 \mathrm{~ns}$ \\
\hline & $5-20$ & $3.71 *$ & 16.38 (10.34)a $\beta$ & 9.55 (7.96) $\alpha \beta$ & $1.95(1.31) \alpha$ & $1.94(1.70)$ & $0.01 \mathrm{~ns}$ \\
\hline & - & $\mathrm{F}$ & $7.86^{* *}$ & $1.80 \mathrm{~ns}$ & $0.51 \mathrm{~ns}$ & $1.39 \mathrm{~ns}$ & \\
\hline \multirow[t]{4}{*}{$10-25$} & $<2$ & $2.89 \mathrm{~ns}$ & $1.42(0.91)$ & $1.56(1.02)$ & $0.31(0.30)$ & $0.61(0.17)$ & $1.74 \mathrm{~ns}$ \\
\hline & $2-5$ & $0.81 \mathrm{~ns}$ & $1.08(0.92)$ & $0.78(0.29)$ & $3.42(6.26)$ & $3.49(6.21)$ & $0.02 \mathrm{~ns}$ \\
\hline & $5-20$ & $1.46 \mathrm{~ns}$ & $4.60(3.08)$ & $3.88(3.48)$ & $1.36(1.63)$ & $0.73(0.20)$ & $0.76 \mathrm{~ns}$ \\
\hline & - & $\mathrm{F}$ & $5.09 \mathrm{~ns}$ & $2.95 \mathrm{~ns}$ & $0.71 \mathrm{~ns}$ & $0.82 \mathrm{~ns}$ & \\
\hline \multirow[t]{4}{*}{ Total (0-25) } & $<2$ & $5.25^{*}$ & $4.70(1.98) \mathrm{b} \alpha \beta$ & 7.43 (3.79)ab $\beta$ & $1.74(0.95) \alpha$ & $3.39(0.85)$ & $2.59 *$ \\
\hline & $2-5$ & 0.01 & $4.20(1.25) \mathrm{b}$ & $4.25(1.99) \mathrm{b}$ & $4.57(6.65)$ & $5.00(6.24)$ & $0.10 \mathrm{~ns}$ \\
\hline & $5-20$ & $6.82 *$ & 20.98 (8.58)a $\beta$ & 13.43 (7.90)a $\alpha \beta$ & $3.31(2.23) \alpha$ & $2.67(1.61)$ & $0.47 \mathrm{~ns}$ \\
\hline & - & $\mathrm{F}$ & $17.26^{* * *}$ & $4.04 *$ & $0.48 \mathrm{~ns}$ & $0.40 \mathrm{~ns}$ & - \\
\hline Total general & - & - & 29.88 & 25.11 & 9.62 & 11.06 & - \\
\hline
\end{tabular}


Tab. 3 - Nutrient contents $\left(\mathrm{g} \mathrm{kg}^{-1}\right)$ of the fine and small roots of three undisturbed forests and disturbed forest in southern Cameroon. Soil depth (cm); RDC: root diameter classes $(\mathrm{mm})$.

\begin{tabular}{|c|c|c|c|c|c|c|c|c|c|c|c|c|c|c|c|c|}
\hline \multirow{3}{*}{$\begin{array}{l}\text { Forest: } \\
\text { Depth: } \\
\text { RDC: }\end{array}$} & \multicolumn{4}{|c|}{ Ebimimbang forest (B) } & \multicolumn{4}{|c|}{ Nyangong forest (N) } & \multicolumn{4}{|c|}{ Undisturbed Ebom forest (A1) } & \multicolumn{4}{|c|}{ Disturbed Ebom forest (A2) } \\
\hline & \multicolumn{2}{|c|}{$0-10$} & \multicolumn{2}{|c|}{$10-25$} & \multicolumn{2}{|c|}{$0-10$} & \multicolumn{2}{|c|}{$10-25$} & \multicolumn{2}{|c|}{$0-10$} & \multicolumn{2}{|c|}{$10-25$} & \multicolumn{2}{|c|}{$0-10$} & \multicolumn{2}{|c|}{$10-25$} \\
\hline & $<2$ & $2-5$ & $<2$ & $2-5$ & $<2$ & $2-5$ & $<2$ & $2-5$ & $<2$ & $2-5$ & $<2$ & $2-5$ & $<2$ & $2-5$ & $<2$ & $2-5$ \\
\hline $\mathrm{N}$ & 13.65 & 8.75 & 7.35 & 6.65 & 11.62 & 13.09 & 12.25 & 13.30 & 18.73 & 20.83 & 17.15 & 21.70 & 14.35 & 18.25 & 15.75 & 16.80 \\
\hline$P$ & & & & & & & & & & & & & & & & \\
\hline & & & & & & & & & & & & & & & & 1.04 \\
\hline$C_{0}$ & 4.93 & 1.13 & & & 4.83 & $7.1^{1}$ & 5.89 & & 108 & 1.64 & & 2.30 & 0.36 & 1.01 & 2.26 & 2.21 \\
\hline $\mathrm{Mg}$ & 0.48 & & & 0.30 & 0.78 & 0.50 & 0.46 & 0.90 & 0.53 & & 0.49 & & 0.74 & & 0.63 & 0.63 \\
\hline $\mathrm{Na}$ & 0.01 & 0.06 & 0.07 & 0.02 & 0.04 & 0.02 & 0.02 & 0.04 & 0.03 & 0.02 & 0.02 & 0.03 & 0.04 & 0.02 & 0.02 & 0.02 \\
\hline
\end{tabular}

Tab. 4 - Comparisons of nutrient amounts $\left(\mathrm{kg} \mathrm{ha}^{-1}\right)$ of roots between soil depths $(0-10$ and 10-25 cm), among three undisturbed forests $(\mathrm{B}, \mathrm{N}$ and $\mathrm{A} 1$ ) and between undisturbed (A1) and disturbed (A2) Ebom forests of southern Cameroon. Standard error in parentheses. $\mathrm{F}_{\mathrm{BNA} 1}$ : Comparisons among three undisturbed forests (B, N and A1); Student $\mathrm{t}_{1}$ : Comparison between soil depths (0-10 and 10-25 cm); Student $\mathrm{t}_{2}$ : Comparison between undisturbed (A1) and disturbed (A2) Ebom forests. Different letters indicate that significant difference among different forest types. (ns): non significant; $(*)$ : $\mathrm{P}<0.05 ;(* *)$ : $\mathrm{P}<0.01 ;(* *)$ : $\mathrm{P}<0.001$.

\begin{tabular}{|c|c|c|c|c|c|c|c|c|}
\hline \multirow{2}{*}{ Roots } & \multirow{2}{*}{ Nutrients } & \multirow{2}{*}{ Depth (cm) } & \multicolumn{4}{|c|}{ Undisturbed forests } & \multicolumn{2}{|c|}{ Disturbed forest } \\
\hline & & & $\mathbf{F}_{\text {BNA1 }}$ & Ebimimang (B) & Nyangong (N) & Ebom (A1) & Ebom (A2) & Student $t_{2}$ \\
\hline \multirow[t]{18}{*}{ Fine Roots } & $\mathrm{N}$ & $0-10$ & $1.4 \mathrm{~ns}$ & $44.72(22.18)$ & $68.27(38.42)$ & $35.66(17.51)$ & $39.91(9.87)$ & $0.4 \mathrm{~ns}$ \\
\hline & & $10-25$ & $1.93 \mathrm{~ns}$ & $10.47(6.68)$ & $19.11(12.50)$ & $6.99(4.66)$ & $9.54(2.68)$ & $0.9 \mathrm{~ns}$ \\
\hline & & & Student $t_{1}$ & $3.31 *$ & $2.72 *$ & $2.74 \mathrm{~ns}$ & $5.94 * *$ & - \\
\hline & $\mathrm{P}$ & $0-10$ & $1.06 \mathrm{~ns}$ & $2.16(1.07)$ & $3.09(1.74)$ & $3.72(1.83)$ & $5.06(1.25)$ & $1.2 \mathrm{~ns}$ \\
\hline & & $10-25$ & $1.29 \mathrm{~ns}$ & $0.56(0.36)$ & $1.03(0.67)$ & $0.56(0.37)$ & $0.85(0.24)$ & $1.3 \mathrm{~ns}$ \\
\hline & & - & Student $t_{1}$ & $3.16^{*}$ & $2.48^{*}$ & $2.94 *$ & $6.60 * * *$ & - \\
\hline & $\mathrm{K}$ & $0-10$ & $4.10 \mathrm{~ns}$ & $14.29(7.09)$ & $21.86(12.30)$ & $3.03(1.49)$ & $2.21(0.55)$ & $1.1 \mathrm{~ns}$ \\
\hline & & $10-25$ & $5.80 *$ & $1.14(0.73) \mathrm{b}$ & $4.74(3.10) \mathrm{a}$ & $0.40(0.27) \mathrm{b}$ & $0.60(0.17)$ & $1.2 \mathrm{~ns}$ \\
\hline & & & Student $t_{1}$ & $4.13^{* *}$ & $3.02 *$ & $3.01 *$ & $5.61 * *$ & - \\
\hline & $\mathrm{Ca}$ & $0-10$ & $5.14 *$ & $16.15(8.01) a b$ & $28.36(15.96) \mathrm{a}$ & $2.06(1.01) \mathrm{b}$ & $0.99(0.25)$ & $2.1 \mathrm{~ns}$ \\
\hline & & $10-25$ & $4.30^{*}$ & $3.75(2.39) \mathrm{ab}$ & $9.19(6.01) \mathrm{a}$ & $0.93(0.62) \mathrm{b}$ & $1.37(0.38)$ & $1.2 \mathrm{~ns}$ \\
\hline & & & Student $t_{1}$ & $3.32 *$ & $2.51 *$ & $1.65 \mathrm{~ns}$ & $1.65 \mathrm{~ns}$ & - \\
\hline & $\mathrm{Mg}$ & $0-10$ & $5.49 *$ & $1.57(0.78) b$ & $4.55(2.56) \mathrm{a}$ & $1.00(0.49) \mathrm{b}$ & $2.07(0.51)$ & $2.8^{*}$ \\
\hline & & $10-25$ & $2.60 \mathrm{~ns}$ & $0.34(0.22)$ & $0.71(0.46)$ & $0.20(0.13)$ & $0.38(0.11)$ & $2.0 \mathrm{~ns}$ \\
\hline & & & Student $t_{1}$ & $3.40 * *$ & $3.30 *$ & $2.73 \mathrm{~ns}$ & $6.46^{* * *}$ & - \\
\hline & $\mathrm{Na}$ & $0-10$ & $6.49^{*}$ & $0.06(0.03) \mathrm{b}$ & $0.24(0.13) \mathrm{a}$ & $0.05(0.02) \mathrm{b}$ & $1.03(0.26)$ & $6.5 * * *$ \\
\hline & & $10-25$ & $4.99 *$ & $0.09(0.06) \mathrm{a}$ & $0.03(0.02) \mathrm{b}$ & $0.01(0.01) \mathrm{b}$ & $0.01(0.003)$ & $1.1 \mathrm{~ns}$ \\
\hline & & & Student $t_{1}$ & $0.99 \mathrm{~ns}$ & $3.36^{*}$ & $2.89 *$ & $8.00 * * *$ & - \\
\hline \multirow[t]{18}{*}{ Small Roots } & $\mathrm{N}$ & $0-10$ & $1.31 \mathrm{~ns}$ & $27.37(8.52)$ & $45.39(26.73)$ & $31.94(8.12)$ & $27.48(8.90)$ & $0.7 \mathrm{~ns}$ \\
\hline & & $10-25$ & $1.93 \mathrm{~ns}$ & $7.16(6.09)$ & $10.39(3.88)$ & $98.70(155.1)$ & $78.19(18.55)$ & $0.2 \mathrm{~ns}$ \\
\hline & & & Student $t_{1}$ & $4.32 * *$ & $2.90 *$ & $0.74 \mathrm{~ns}$ & $4.95 *$ & - \\
\hline & $\mathrm{P}$ & $0-10$ & $3.03 \mathrm{~ns}$ & $1.23(0.38)$ & $1.83(1.08)$ & $2.64(0.67)$ & $2.54(0.82)$ & $0.2 \mathrm{~ns}$ \\
\hline & & $10-25$ & $2.07 \mathrm{~ns}$ & $0.42(0.36)$ & $0.51(0.19)$ & $8.17(12.85)$ & $6.55(9.93)$ & $0.2 \mathrm{~ns}$ \\
\hline & & & Student $t_{1}$ & $3.43 * *$ & $2.69 *$ & $0.75 \mathrm{~ns}$ & $0.81 \mathrm{~ns}$ & - \\
\hline & $\mathrm{K}$ & $0-10$ & $5.36^{*}$ & $4.16(1.30) \mathrm{ab}$ & $10.18(6.00) \mathrm{a}$ & $1.63(0.41) \mathrm{b}$ & $1.91(0.62)$ & $0.7 \mathrm{~ns}$ \\
\hline & & $10-25$ & $1.51 \mathrm{~ns}$ & $1.24(1.05)$ & $0.82(0.31)$ & $5.50(8.64)$ & $4.85(7.35)$ & $01 \mathrm{~ns}$ \\
\hline & & & Student $t_{1}$ & $3.91 * *$ & $3.49 * *$ & $0.77 \mathrm{~ns}$ & $0.74 \mathrm{~ns}$ & - \\
\hline & $\mathrm{Ca}$ & $0-10$ & $7.53 *$ & 3.54 (10.95)ab & $24.85(14.63) \mathrm{a}$ & $2.52(1.64) b$ & $1.53(0.49)$ & $2.2 \mathrm{~ns}$ \\
\hline & & $10-25$ & $0.42 \mathrm{~ns}$ & $8.08(6.88)$ & $4.87(1.82)$ & $10.48(16.48)$ & $10.28(15.58)$ & $0.02 \mathrm{~ns}$ \\
\hline & & & Student $t_{1}$ & $4.69 * *$ & $3.03 *$ & $0.84 \mathrm{~ns}$ & $0.51 \mathrm{~ns}$ & - \\
\hline & $\mathrm{Mg}$ & $0-10$ & $4.26^{*}$ & $0.78(0.24) b$ & $1.72(1.01) \mathrm{a}$ & $0.44(0.11) b$ & $0.38(0.12)$ & $0.7 \mathrm{~ns}$ \\
\hline & & $10-25$ & $1.96 \mathrm{~ns}$ & $0.32(0.03)$ & $0.70(0.26)$ & $3.52(5.54)$ & $2.91(4.41)$ & $0.2 \mathrm{~ns}$ \\
\hline & & & Student $t_{1}$ & $6.85^{* * *}$ & $2.18 \mathrm{~ns}$ & $0.97 \mathrm{~ns}$ & $0.49 \mathrm{~ns}$ & - \\
\hline & $\mathrm{Na}$ & $0-10$ & $11.15^{*}$ & $0.19(0.06) \mathrm{a}$ & $0.08(0.05) \mathrm{b}$ & $0.04(0.01) b$ & $0.03(0.01)$ & $1.1 \mathrm{~ns}$ \\
\hline & & $10-25$ & $1.60 \mathrm{~ns}$ & $0.02(0.02)$ & $0.03(0.01)$ & $0.15(0.24)$ & $0.08(0.12)$ & $0.5 \mathrm{~ns}$ \\
\hline & & & Student $t_{1}$ & $6.15^{* * *}$ & $2.27 \mathrm{~ns}$ & $0.83 \mathrm{~ns}$ & $0.69 \mathrm{~ns}$ & - \\
\hline
\end{tabular}


Tab. 5 - Root biomass $\left(\mathrm{t} \mathrm{ha}^{-1}\right)$ and their nutrient contents $\left(\mathrm{g} \mathrm{kg}^{-1}\right)$ of tropical rainforests. $(*)$ : Source: Noij et al. (1993). TRP: total root phytomass; FR: Fine roots $(\leq 6 \mathrm{~mm})$; DC: Diameter class for the fine roots. (1): total depth: 0-25 cm; (2): total depth 0-50 cm.

\begin{tabular}{|c|c|c|c|c|c|c|c|c|c|}
\hline Country & TRP & DC (mm) & FR phytomass & $\mathbf{N}$ & $\mathbf{P}$ & $\mathbf{K}$ & Ca & Mg & Sources \\
\hline \multicolumn{10}{|c|}{ Oxisols/Ultisols (infertile soils) } \\
\hline \multirow[t]{5}{*}{ Cameroon } & $9.6-29.9^{1}$ & - & - & - & - & - & - & - & This study \\
\hline & - & $<2$ & $1.7-7.4$ & 7.4-18.7 & $0.4-2.0$ & $0.8-4.4$ & $1.1-5.9$ & $0.2-0.8$ & This study \\
\hline & - & $2-5$ & $4.2-4.6$ & $6.7-21.7$ & $0.4-1.8$ & $1.1-2.9$ & $1.1-7.5$ & $0.3-0.9$ & This study \\
\hline & - & $5-20$ & $3.3-21.0$ & - & - & - & - & - & This study \\
\hline & $44.5^{2}$ & - & - & - & - & - & - & - & Kanmegne 2004 \\
\hline Ghana (Kumasi) & - & $5 / 6$ & - & 10.00 & 0.14 & 0.69 & 1.10 & 0.62 & Greenland \& Kowal 1960 \\
\hline Brazil & 32.2 & 6 & 14.57 & - & - & - & - & - & Klinge et al. 1975 \\
\hline \multirow[t]{3}{*}{ Venezuela } & - & 6 & 2.0 & - & - & - & - & - & Jordan \& Escalante 1980* \\
\hline & - & 2 & 15.4 & - & - & - & - & - & Sanford $1980 *$ \\
\hline & 56 & 6 & 32 & - & - & - & - & - & Stark \& Pratt $1977^{*}$ \\
\hline \multicolumn{10}{|c|}{ Other soil types } \\
\hline \multirow[t]{2}{*}{ Costa Rica } & - & 2 & 2.7 & - & - & - & - & - & Raich 1980* \\
\hline & 14.4 & 2 & 2.9 & - & - & - & - & - & Jordan 1985 \\
\hline \multirow[t]{2}{*}{ Venezuela } & - & 6 & 32.9 & - & - & - & - & - & Herrera \& Klinge 1978* \\
\hline & 132.2 & 6 & 92.5 & - & - & - & - & - & Klinge et al. 1975 \\
\hline Ghana (Kade) & 22.1 & $5 / 6$ & 4.45 & 8.1 & 0.8 & 5.6 & 8.8 & 2.0 & Greenland \& Kowal 1960 \\
\hline Nouvelle Guinée & 40.0 & 5 & 2.8 & 7.5 & 0.3 & 3.9 & 7.1 & 6.1 & Grubb \& Edwards 1982* \\
\hline Porto Rico & - & $5 / 6$ & - & 7.0 & 0.3 & 4.2 & 5.6 & 1.8 & Ovington \& Olsen $1970^{*}$ \\
\hline \multirow[t]{2}{*}{ Venezuela } & - & $5 / 6$ & - & - & 1.2 & 7.1 & 9.3 & 2.7 & Hase \& Fölster 1982* \\
\hline & - & $5 / 6$ & - & 10.0 & 0.1 & 0.7 & 1.1 & 0.6 & Golley et al. $1980^{*}$ \\
\hline \multirow[t]{2}{*}{ Tropical forests } & - & $5 / 6$ & - & 6.7 & 0.6 & 2.9 & 1.6 & 1.4 & Vitousek \& Sanford 1986 \\
\hline & - & $5 / 6$ & - & 10.7 & 0.3 & 1.1 & 1.2 & 1.5 & Vitousek \& Sanford 1986 \\
\hline
\end{tabular}

depth of $10-25 \mathrm{~cm}$. On the other hand, for fine root at a depth of 10-25 cm, a decrease in $\mathrm{Mg}$ content is witnessed from Ebom $(0.5 \mathrm{~g}$ $\left.\mathrm{kg}^{-1}\right)$ to Ebimimbang $\left(0.2 \mathrm{~g} \mathrm{~kg}^{-1}\right)$. For the other nutrient contents, no clear trend of variation was noticed among the three forests.

There is a significant difference in the total nutrient amounts $\left(\mathrm{kg} \mathrm{ha}^{-1}\right)$ between the three forests (Tab. 4). Contrary to the situation at Ebom where only $\mathrm{P}, \mathrm{K}$ and $\mathrm{Na}$ amounts of fine roots decrease significantly with soil depth, generally in Ebimimbang and Nyangong, all the nutrients decrease significantly with depth, except $\mathrm{Na}$ in fine roots at Ebimimbang, and $\mathrm{Mg}$ and $\mathrm{Na}$ in small roots at Nyangong (Tab. 4). The nutrient amounts in small roots at a depth of $10-25 \mathrm{~cm}$ do not differ significantly among forest. For $\mathrm{N}$ and $\mathrm{P}$, there is no significant difference among forests with any diameter class and soil

depth, while the amounts of $\mathrm{Ca}$ and $\mathrm{Na}$ differ significantly in these three forest types, with the exception of the small roots at a depth of $10-25 \mathrm{~cm}$ (Tab. 4). For $\mathrm{Mg}$, it is at the top soil that the quantity in roots (fine and small) varies significantly among the forests. In most of the case, the nutrient amounts decrease from Nyangong to Ebom, with some exceptions like the quantities of $\mathrm{Ca}$ and $\mathrm{Na}$ at Ebimimbang.

\section{Variation between undisturbed and dis- turbed forest at Ebom}

Generally, the N, P, K and Ca contents are higher in the undisturbed than in the disturbed forest (Tab. 3). The Mg content in the fine roots is higher in the disturbed than the undisturbed forest, while in the small roots the variation in the $\mathrm{Mg}$ content is other way round, however not significantly. The $\mathrm{Na}$ content is the similar in the two forest types.

Tab. 6 - Variation of soil available $\mathrm{P}$, total $\mathrm{K}, \mathrm{Mg}, \mathrm{Ca}$ and $\mathrm{N}$, and soil water content among three undisturbed forests. Values in $\mathrm{kg} \mathrm{ha}^{-1}$. Source: van Gemerden \& Hazeu (1999). (*): at 0 $-20 \mathrm{~cm}$ of depth. All elements in soil column of $1 \mathrm{~m}$.

\begin{tabular}{lrcc}
\hline \multicolumn{1}{c}{ Elements } & Ebom & Ebimimbang & Nyangong \\
\hline Total N & 8900 & 7000 & 12500 \\
Available P & 28 & 24 & 8 \\
$\mathrm{~K}$ & 755 & 370 & 360 \\
$\mathrm{Mg}$ & 175 & 165 & 195 \\
$\mathrm{Ca}$ & 1785 & 1810 & 1065 \\
Water content available (\%)* & 17 & 11 & 10 \\
\hline
\end{tabular}

The nutrient amounts in the roots vary with the soil depth and the root diameter classes in the disturbed forest (Tab. 4). For this forest, the amount of $\mathrm{N}, \mathrm{P}, \mathrm{K}, \mathrm{Mg}, \mathrm{Na}$ decrease significantly with soil depth, only in the fine roots contrary to $\mathrm{Ca}$ amount $\left(\mathrm{t}_{1}=\right.$ $1.65, \mathrm{P}>0.05)$.

On the whole, the nutrient amount of the roots do not differ significantly between the disturbed and undisturbed forest, except for $\mathrm{Mg}\left(\mathrm{t}_{2}=2.8, \mathrm{P}<0.05\right)$ and $\mathrm{Na}$ amount $\left(\mathrm{t}_{2}=\right.$ $6.50, \mathrm{P}<0.001)$ whose quantity in fine roots is significantly higher in the disturbed than undisturbed forest.

\section{Discussion}

Comparison with literature data

The root biomasses found in the present study fall in the same range of data from other rainforests (Tab. 5). Indeed, in south Cameroon, the total biomass for a soil depth of $0-25 \mathrm{~cm}$ range between 10 and $30 \mathrm{t} \mathrm{ha}^{-1}$, with the fine roots (diameter $<2 \mathrm{~mm}$ ) from 2 to $7 \mathrm{t} \mathrm{ha}^{-1}$, small roots (diameter $2-5 \mathrm{~mm}$ ) from 4 to $5 \mathrm{tha}^{-1}$ and medium roots (diameter $5-20 \mathrm{~mm}$ ) from 3 to $21 \mathrm{t} \mathrm{ha}^{-1}$. In the Campo Ma'an National park, also in southern Cameroon, Kanmegne (2004), found $45 \mathrm{t}$ $\mathrm{ha}^{-1}$ roots at a total soil depth of $50 \mathrm{~cm}$. Values found elsewhere show that total root biomass range from 14 to $45 \mathrm{t} \mathrm{ha}^{-1}$, with, 2$33 \mathrm{t} \mathrm{ha}^{-1}$ fine and small root (diameter $\leq 6$ $\mathrm{mm}$ - Tab. 5). In the Venezuelan forest, 
Klinge et al. (1975) came up with an exceptional high value of $132 \mathrm{t} \mathrm{ha}^{-1}$ for all roots and $93 \mathrm{tha}^{-1}$ for small roots only.

Data from the literature on the nutrien contents of root differ from our results in respect of on the nutrient considered and soil type (Tab. 5). The values found in the present study are higher than those of the literature concerning the infertile soil (Oxisols/Ultisols). The results of Greenland \& Kowal (1960) in the Ghanian humid forests, on the same soil type as those of the forests in which we carried out our experiences are generally lower than ours. This is an indication that, in spite of the spatial heterogeneity of nutrient contents in fine roots, the south Cameroon forests belong to the rainforests, rich in nutrients although growing on poor soils (Oxisols/Ultisols).

Influence of soil depth on the vertical distribution of fine root and their nutrients

The distribution of the fine roots, as well as the nutrient amount of the three undisturbed forests decrease significantly with soil depth Eighty two, 79 and $70 \%$ of the fine root biomass are produced in the top layer $(0-10$ $\mathrm{cm})$, respectively at Ebom, Nyangong and Ebimimbang. This vertical distribution is in conformity with those reported in other tropical forests (Castellanos et al. 2001). Physical as well as chemical properties of the soils, in as much as the accumulation of litter and organic matter in the topsoil and availability of water led to fine root accumulation in the topsoil (Marschner 1991).

Soil texture can equally constitute a factor that is likely to explain this distribution in depth in our study, since the clay percentage increases with soil depth in the three undisturbed forest types (Tab. 1). Furthermore, fine root development in the topsoil, especially in oligotrophic forests is often considered as a nutrient conservation mechanism (Jordan 1991). Stark \& Jordan (1978) have shown that fine roots are constitute an efficient nutrient trap, capable of recovering more than $99 \%$ of $\mathrm{P}$ and $\mathrm{Ca}$, spread in the topsoil.

Spatial variation of root biomass and their nutrient content in the undisturbed forests

The distribution of fine root biomass in the topsoil layer varies in the three forest types. They constitute 54,34 and $12 \%$ of the total biomass respectively at Nyangong, Ebimimbang and Ebom. The share of small roots is equal in these forests, with 33, 32 and 35\% respectively at Nyangong, Ebimimbang and Ebom. A comparison of different rainforests has shown that a higher root biomass production occurs in sites that are poor in nutrients (Klinge 1984). Noij et al. (1993) also reported that fine root biomass development is related to soil fertility, that is, the availability of nutrients, especially phosphorus $(\mathrm{P})$ which serves as a limiting factor in the absence of mycorhizia associations, but under conditions where the supply of $\mathrm{P}$ is adequate, with all other nutrient becoming limiting for the growth.

Likewise, the three undisturbed forests differ in the nutrient contents in roots. In fact, the variation trend of $\mathrm{N}$ and $\mathrm{P}$ contents among the forests are similar; with these elements contents tending to decrease from Ebom to Ebimimbang respectively for the two diameter classes for a depth of $10-25 \mathrm{~cm}$ and for small roots for a depth of $0-10 \mathrm{~cm}$ (Tab. 3). On the contrary, in the topsoil layer, these two nutrients in fine roots tend to decrease from Ebom to Nyangong. The total amounts of the two elements, particularly that of $\mathrm{P}$ are also decreased from Ebom $\left(15.09 \mathrm{~kg} \mathrm{ha}^{-1}\right)$ to Nyangong $\left(6.46 \mathrm{~kg} \mathrm{ha}^{-1}\right)$. This variation is inversely related to the fine root biomass variation, which decreases from the Nyangong forest to that of Ebom.

Van Gemerden \& Hazeu (1999) have shown that the availability of water content in the three forests and the available $\mathrm{P}$ and $\mathrm{K}$ amounts in the soil (column of $1 \mathrm{~m}$ ) decrease from the Ebom forest toward that of Nyangong (Tab. 6). This fact partially explains the spatial heterogeneity of the root biomass variation as well as their $\mathrm{P}$ amount among these three forests and, confirms the results of Whitmore (1998) who has shown that the production of fine roots in the topsoil and their nutrient contents vary with soil quality. In infertile soils as that of Nyangong (low P amount), the production of fine roots is high and the nutrient contents are low. Inversely, in fertile soils such as in Ebom (high $\mathrm{P}$ amount), fine root biomass is low and the nutrient contents are high. Vitousek \& Sanford (1986) have shown that the fine root turnover can also influence their spatial distribution and their nutrient contents. Unfortunately, the turnover of roots has not been studied in the present work. According to Vitousek \& Sanford (1986), it takes place at rate of $25 \%$ per month in the first $10 \mathrm{~cm}$ of the Venezuelan soils of the Oxisols type. For the other nutrients, no clear trend is observed in the three undisturbed forests.

Impact of logging on the fine root biomass and their nutrients changes

In this study, differences between the disturbed and undisturbed forests of Ebom are not significant with regard to root biomass and nutrient amounts, except for $\mathrm{Mg}$ and $\mathrm{Na}$ which are significantly higher in the disturbed than undisturbed forest. This suggests that the impact of selective logging on root biomass and their nutrient loss in Ebom is relatively small and recovery of fine roots was relatively fast. In fact, Van Gemerden \& Hazeu (1999) have shown that less than a tree per hectare was logged during the last exploitation and this means intensity of logging was low in this forest. Van Dam (2001) found that the effect of disturbance caused by extracting 1 or 2 trees from stand on the leaching of $\mathrm{N}, \mathrm{K}, \mathrm{Ca}$ and $\mathrm{Mg}$ is less serious than the disturbance caused by the logging from 5 to 10 trees. In addition, Van Gemerden (2004) has reported that recovery of basal area, plant density and species composition was relatively fast in Cameroon, particularly in Ebom forest. Basal area and plant density recovered in 5 years and floristic recovery took 14 years in logged areas. Comparing to other tropical rainforests, structural recovery following selective logging took more than 50 years in Uganda (Plumptre 1996) and floristic recovery in other regions ranged from 40 to 200 years (Kurpick et al. 1997, Aide et al. 2000). We found after logging, 6 or 7 years have occurred before this assessment and the difference between disturbed and undisturbed forest was not significant. This suggested that the recovery of the fine and small roots took place 5 to 6 years as found by Van Gemerden (2004) for basal area and plant density. In logging gaps, mass destruction of dominant vegetation cover occurs but generally many seedling and saplings survive the crown fall (Whitmore 1991) and contribute considerably to the filling of canopy gaps (Parren \& Bongers 2001). As a consequence, regeneration in most logging sites was formed by individuals that were already present before disturbance and pioneers species like Musanga cecropioides.

\section{Conclusion}

Our study shows that root biomass in the Cameroonian rainforest - especially of fine roots - are among of the lower values found in other tropical rainforests, growing on the similar soils type as the Oxisols/Ultisols. Fine root biomass decreases with soil depth. Spatial distribution of fine root biomass varies between forest types, especially in the upper of soil layers. Ebom forest has a lowest root production and highest available $\mathrm{P}$ amount in the root, while Nyangong forest has highest root production and lowest available P amount and Ebimimbang is intermediate according its root production and available $\mathrm{P}$ amount. $\mathrm{Mg}$ was found in low quantities in root biomass, especially at Ebom forest. Logging activities provoked nutrient deficit, especially $\mathrm{N}, \mathrm{P}$ and $\mathrm{Ca}$ that is generally present in low amounts in soil, and an increase of the root biomass, especially those of fine roots for landing to nutrient deficits in soils. But, fast fine root recovery, less than 7 years and low extraction of logs from a stand and relative small effects of logging systems on the site lead to insignificant nutrient losses. 


\section{Acknowledgements}

This work has been done in Tropenbos Cameroon Programme for sustainable management forest of south west of Cameroon, with financing of European commission. The authors thank MAB Ayangma, C Kana and MM Mva for their field and laboratory assistance and technicians of the Laboratoire des Sols et de l'Environnement of the University of Dschang, Cameroon for their chemical analysis.

\section{References}

Aide TM, Zimmerman JK, Pascarella JB, Rivera L, Marcano-Vega H (2000). Forest regeneration in a chronosequence of tropical abandoned pastures: implications for restoration ecology. Restoration Ecology 8: 328-338. - doi: 10.1046/ j.1526-100x.2000.80048.x

Archard F, Eva HD, Stibig HJ, Mayaux P, Gallego J, Richards T, Mallingreau JP (2002). Determination of deforestation rates of the world's humid tropical forests. Science 297: 999-1002. - doi: 10.1126/science. 1070656

Castellanos J, Jaramillo VJ, Sanford RL, Kauffman JB (2001). Slash-and-burn effects on fine root biomass and productivity in tropical dry forest ecosystem, México. Forest Ecology and Management 148: 41-50. - doi: 10.1016/S03781127(00)00523-5

Fines JP, Ngibaot F, Ngono G (2001). A conceptual forest management plan for a medium size forest in southern Cameroon. Tropenbos-Cameroon Documents 6, The Tropenbos-Cameroon Programme, Kribi, Cameroun.

Foahom B, Jonkers WBJ (1992). A programme for tropenbos research in Cameroon. Final report. The tropenbos fondation, Wageningen, The Netherlands.

Franqueville A (1973). Atlas régional Sud-Ouest I, République du Cameroun. ORSTOM, Yaoundé, Cameroun.

Greenland DJ, Kowal JM (1960). Nutrient content of the moist tropical forest of Ghana. Plant and Soil 12: 154-174. - doi: 10.1007/BF01377368

Hendrick RL, Pregitzer KS (1993). The dynamics of fine root length, biomass and nitrogen content in two northern hardwood ecosystems. Canadian Journal of Forest Research 23: 2507-2520. - doi: 10.1139/x93-312

Hendricks JJ, Hendricks RL, Wilson CA, Mitchell RJ, Pecot SD, Guo D (2006). Assessing the patterns and controls of fine root dynamics: an empirical test and methodological review. Journal of Ecology 94: 40-57. - doi: 10.1111/j.13652745.2005.01067.x

Hoffmann CW, Usoltsev VA (2001). Modelling root biomass distribution in Pinus sylvestris forests of the Turgai depression of Kazakhstan. Forest Ecology Management 149: 103-114. - doi: 10.1016/S0378-1127(00)00548-X

Jonkers WBJ, Van Leersum GJR (2000). Logging in south Cameroon: current methods and opportunities for improvement. International Forestry
Review 2 (1): 11-16.

Jordan CF (1985). Nutrient cycling in tropical forest ecosystems. Wiley \& Sons, Chichester, UK.

Jordan CF (1991). Nutrient cycling processes and tropical forest management. In: "Rain forest regeneration and management" (Gomez-Pompa A, Whitmore TC, Hadley M eds). UNESCO, Paris, France, pp. 90-106.

Kanmegne J (2004). Slash and burn agriculture in the humid forest zone of southern Cameroon: soil quality dynamics, improved fallow management and farmers' perceptions. $\mathrm{PhD}$ thesis, Wageningen University and Research Centre, The Netherlands, pp. 185.

Klinge H (1984). Lowland Amazon forests, bioelements and geochemistry. In: Proc. $1^{\circ} \mathrm{Sim}-$ posio do Tropico Umido, Belem, Brazil, pp. 333346.

Klinge H, Rodrigues WA, Bruning E, Fittkau J (1975). Biomass structure in a central Amazonian rain forest. In: "Tropical ecological systems" (Golley FB, Medina E eds). Springer Verlag, New York, USA, pp. 115-122.

Kotto-same J, Woomer PL, Moukam A, Zapfack L (1997). Carbon dynamics in slash-and-burn agriculture and land use alternatives of the humid forest zone in Cameroon. Agriculture, Ecosystems and Environment 65: 245-256. - doi: 10.1016/S0167-8809(97)00060-1

Kurpick P, Kurpick U, Huth A (1997). The influence of logging on a Malaysian dipterocarp rain forest: a study using a forest gap model. Journal of Theoretical Biology 185: 47-54. - doi: 10.1006/jtbi.1996.0288

Letouzey R (1985). Notice de la carte phytogéographique du Cameroun au 1:500.00. Institut de la Carte Internationale de la Végétation, Toulouse, France.

Marschner H (1991). Mechanisms of adaptation of plants to acid soils. Plant and Soil 134: 1-20. doi: 10.1007/BF00010712

Noij IGM, Janssen BH, Wesselink LG, van Grinsven JJM (1993). Modelling nutrient and moisture cycling in tropical forests. Tropenbos-series 4, The Tropenbos Fondation.

Noordwijk M, van Lawson G, Soumaré A, Groot JJR, Hairiah K (1996). Root distribution of trees and crops: competition and/or complementarit. In: "Tree-crop interactions: a physiological approach" (Ong CK, Huxley P eds). CAB International, Washington, Oxon, GB, 386 S, pp. 319364.

Nounamou L, Yemefack M (2000). Shifting cultivation in the evergreen forest of southern Cameroon: farming systems and soil degradation. Tropenbos-Cameroon Reports 00-02, The Tropenbos-Cameroon Programme, Kribi, Cameroun, pp. 58.

Ntonga JC, Waterloo, MJ, Ayangma A (2002). Hydrology, erosion and nutrient cycling in a forest ecosystem in southern Cameroon. Tropenbos-Cameroon Documents 10, The Tropenbos-Cameroon Programme, Kribi, Cameroun, pp.
60.

Olivry JC (1986). Fleuves et rivières du Cameroun. Collection Monographe Hydrologiques d'ORSTOM nº 9. MESRES-ORSTOM, Paris, France.

Parren M, Bongers F (2001). Does climber cutting reduce felling damage in southern Cameroon? Forest Ecology and Management 141: 175-188. doi: 10.1016/S0378-1127(00)00327-3

Plumptre AJ (1996). Changes following 60 years of selective timber harvesting in the Budongo Forest Reserve, Uganda. Forest Ecology and Management 89: 101-113. - doi: 10.1016/S03781127(96)03854-6

Saterson KA, Vitousek PM (1984). Fine root biomass and nutrient cycling in Aristida stricta in a North Carolina coastal plain Savanna. Canadian Journal of Botany 62: 823-829. - doi: 10.1139/b84-120

Stark NM, Jordan CF (1978). Nutrient retention by the root mat of an Amazonian rain forest. Ecology 59: 434-437. - doi: 10.2307/1936571

Van Dam O (2001). Forest filled with gaps: effects of gap size on water and nutrient cycling in tropical rain forest. A study in Guyana. Tropenbos - Guyana Series 10, pp. 208.

Van Dijk JFW (1999). Non-timber forest products in the Bipindi - Akom II region, Cameroon: a socio-economic and ecological assessment. Tropenbos-Cameroon Series 1. The Tropenbos-Cameroon Programme, Kribi, Cameroun, pp. 197.

Van Gemerden BS (2004). Disturbance, diversity and distributions in Central Africa rain forest. Ph.D. Thesis, Wageningen University, The Netherlands, pp. 199.

Van Germerden BS, Hazeu GW (1999). Lanscape ecological survey $(1: 100.00)$ of the Bipindi Akom II-Lolodorf region southwest Cameroon. Tropenbos-Cameroon documents 1, The Tropenbos-Cameroon Programme, Kribi, Cameroun, pp. 164.

Vitousek PM, Sanford RL (1986). Nutrient cycling in moist tropical forest. Annual Review of Ecology and Systematics 17: 137-167. - doi: 10.1146/annurev.es.17.110186.001033

Vogt KA, Grier CC, Vogt DJ (1986). Production, turnover and nutrient dynamics of above- and belowground detritus of world forests. Advances in Ecological Research 15: 303-377. - doi: 10.1016/S0065-2504(08)60122-1

Vogt KA, Persson H (1991). Measuring growth and development of roots. In: "Techniques and approaches in forest tree ecophysiology" (Lassoie JP, Hinckley TM eds). Boca, pp. 477-501.

Whitmore TC (1991). Tropical rain forest dynamics and its implications for management. In: Rain forest regeneration and management (Gomez-Pompa A, Whitmore TC, Hadley M eds), UNESCO, Paris, France, pp. 67-89. - doi: 10.1017/S0266467400002911

Whitmore TC (1998). An introduction to tropical rain forests $\left(2^{\text {nd }} \mathrm{edn}\right)$. Oxford University Press, New York, Tokyo, pp. 282. 